\title{
The Derivation Errors Made By Students in Completing Paragraph of The Third Semester Students at FKIP UIR
}

\author{
Rides Sujatmiko \\ STIE Prakarti Mulya \\ E-mail: sujatmikorides@gmail.com
}

\begin{abstract}
In derivational word have meaning adding affixes; there are three kinds of affixes. Includes of suffix, prefix and infix to word in this research the writer want to know the third semester students at FKIP UIR capability in changing the derivational word. This research is descriptive quantitative there are one variable in this research. The location of this research was in English department of FKIP UIR and the writer took the data on November 20011 there are seven class in third semester that consist of 317 student as population and the sample of this research was 47 students in $3 \mathrm{c}$ class. There is one instrument in this research, it is test and this test was given consist of three test. It was used to know students ability in changing the derivational word. From the data analysis, it can be seen for the first test there are $89,36 \%$ students feel difficult in changing infix $87,23 \%$ students feel difficult in changing suffix and $0 \%$ in changing prefix, after that from the second test there are $100 \%$ students feel difficult in changing infix, $80,85 \%$ students feel difficult in changing suffix and $21,27 \%$ students feel difficult in changing prefix and the last test there are $95,74 \%$ students feel difficult in changing infix, 87,23\% students feel difficult in changing suffix and 68,08\% students feel difficult in changing prefix, so it can be concluded the students more difficult in changing derivational word into infix. It can be seen from the explanation above from three times taken the data.
\end{abstract}

Keywords : derivational word, completing paragraph 


\section{INTRODUCTION.}

English is one of international languages for communication. It is used by more than one half of the one billion English speakers of the world. It is learned either as a second or a foreign language. English has an important role as one of international communication media that is not only as tool of communication for each school in the world but also most of the scientific books are written in English. Samovara and Porter (1995:151) state that "English is the primary language for many of us", and Brown (1994:122) says that"English is increasingly being used as a tool for interaction among nonnative speakers. but also as tool of communication in politics, economy, and education.

People need to communicate in their life. They need to express their feeling, want, and desire to get what they want, especially communication is very important at SMK Bina Profesi Pekanbaru. The students of this school need to improve their speaking confidence by using a group method, one of its method is cooperative learning. Cooperative learning is both an instructional technique and a teaching philosophy that encourages students to work together or maximise their own learning and the learning of their peer (Killen, 1998:82).

In recent years, one of a new era in which English speaking instruction must give a chance for students to express themselves in speaking the language. A promising method to traditional speaking instruction is cooperative learning. It serves as an alternative way of teaching for promoting speaking and social interaction among students (Gomleksiz, 2007; Ning, 2011). Prior research suggests that cooperative learning is of great effect on developing students'speaking confidence (Pattanpichet, 2011; Liao, 2009) and also in improving their attitudes towards learning (Slavin, 1995).

Teachers have done many ways to increase their students' ability in speaking confidence but they are unsuccessful, the teacher gives more materials which are dominated by grammar focus, students cannot speak fluently because they are lack of practice English. However, the students at SMK Bina Profesi Pekanbaru are still weak in speaking confidence and find difficulty in expressing themselves in English. Bose (2002) and Al-Sohbani (2013) state that speaking at schools are typically taught in small classes by teachercentered lecturing, which ends up with skills of memorisation and recall, where by students memorise their lessons and simply regulate the contents on demand.

From the statement above, curriculum based on competence in school tries to develop and achieve the communicative competence or discourse competence and has perspective that is comprehensive to the discourse. The learners must be able to master components speaking such as pronounciation, fluency, 
grammar, vocabulary and interacive communication. English teachers at SMK Bina Profesi Pekanbaru deliver the materials which are dominated by grammar focus as the result, the students cannot speak English fluently because lack of practice and use of spoken English themselves, in line with it, this study is expected to improve whether a cooperative learning gives the effect to improve students' speaking confidence.

Considering all the facts explained above, the investigation is used cooperative learning teaching strategy to solve the problems, because to get some information about learning process in the classroom expecially in speaking confidence, based on the interview some of English teachers at Vocational High School Bina Profesi Pekanbaru, some of students cannot reach the minimum Criteria achievement (KKM). The teacher from Vocational High School Bina Profesi Pekanbaru said the school had done to teach English method but also unsuccess to increase speaking confidence toward attitude.

In this view, there is a central focus on grammar and vocabulary at the expense of communication. The students are provided with detailed rules and formulas about grammar (Bose, 2002). Based on preliminary study in November 2007, it used curriculum KTSP, teachers seem to do the most talking and act as the only source of knowledge to students, while students are treated as passive recipients in the learning process. This type of methods, according to
Gomleksiz, (2007), has negatively affected students and produced incompetent users of the English language who are unable to improve their speaking confidence in EFL classes. The phenomena are some students cannot speak English properly, some students cannot use pronunciation English properly, more students cannot use grammar properly, more students cannot speak English fluently, and then in majority of students cannot interact

\section{METHOD}

This research was descriptive quantitative research. This research consist of one variable, which are forming verbs, adjectives, adverbs, into noun error in writing paragraph, that made by the third semester students of English department of UIR.

Based on the background above, so these researches have been done in the English department at FKIP UIR, and these researches have conducted on November 2011 at the Third Semester of English in FKIP UIR.

Population

The population of this research there are seven classes (class A until G) of the third semester of English study program of FKIP UIR Pekanbaru in academic year 2011/2012. There are 317 students in seven classes. 
Table 1.

\begin{tabular}{|c|c|c|}
\hline NO & Class & Population \\
\hline 1 & $3 \mathrm{~A}$ & 46 \\
\hline 2 & $3 \mathrm{~B}$ & 45 \\
\hline 3 & $3 \mathrm{C}$ & 47 \\
\hline 4 & $3 \mathrm{D}$ & 40 \\
\hline 5 & $3 \mathrm{E}$ & 42 \\
\hline 6 & $3 \mathrm{~F}$ & 48 \\
\hline No & Class & Population \\
\hline 7 & $3 \mathrm{G}$ & 49 \\
\hline \multicolumn{3}{|c|}{ TOTAL } \\
\hline
\end{tabular}

The population of this research of Because of this population is large so the researcher takes $15 \%$. Based on Winarno theory if the population more than 100 , so the sample of this research is 47 . So this sample will be conducted in $3 \mathrm{C}$.

\section{Instrumentation}

Test

This test is written test. It was used to measure students' ability in writing and use prefix, suffix and infix in completing paragraph.

Table 2.

\begin{tabular}{|c|l|l|c|}
\hline No & $\begin{array}{c}\text { Data } \\
\text { colletion } \\
\text { Tecnique }\end{array}$ & Indicators & Topic \\
\hline 1 & Test & - Students & 1. My \\
& & ability in & son \\
& & using & Josh \\
& prefix, & ua \\
& suffix and & 2. Sou \\
& infix. In & rces \\
& writing & of \\
& & paragraph & stress \\
& & - Students & 3. Ada \\
\hline
\end{tabular}

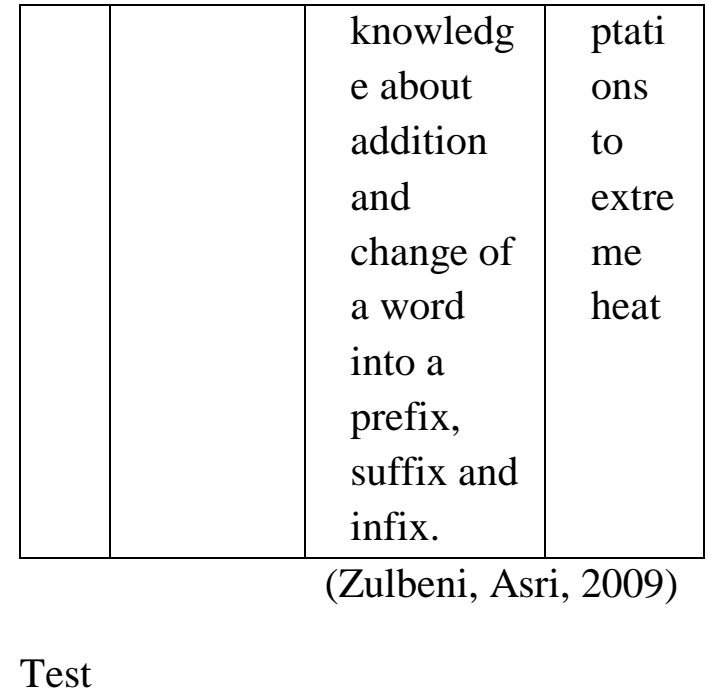

To take this data, the writer gives a test to the students. The writer done three times test, there are three title that done by student in completing paragraph (prefix, suffix, and infix).

The data analyzed by using the statistical method.

Table 3.

\section{Range to Measure Students Test}

\begin{tabular}{|c|c|}
\hline Score & Category \\
\hline $0-40 \%$ & Easy \\
\hline $40-100 \%$ & Difficult \\
\hline
\end{tabular}

(Hughes, 1989:76)

If the " $\mathrm{D}$ " is smaller than or equal to $40 \%$, then the category is considered to be easy. Meanwhile, if the " $\mathrm{D}$ " is bigger than $40 \%$, then the category is considered to be difficult one (Hughes, 1989:76) in John T (2007:16).

\section{FINDINGS AND DISCUSSION}

In this research, the instruments that used to measure students ability in using derivational word is test. After 
taken this data, so the writer calculates the result of students test. The result as follow:

Table 4.

The Difficulty Level of Derivation in the Test

\begin{tabular}{|c|c|c|c|}
\hline $\begin{array}{l}\mathbf{N} \\
\mathbf{o}\end{array}$ & $\begin{array}{c}\text { Prefixe } \\
\text { s }\end{array}$ & $\begin{array}{c}\text { Percentag } \\
\text { e }\end{array}$ & $\begin{array}{l}\text { Criteri } \\
\quad \mathbf{a}\end{array}$ \\
\hline 1 & In & $0 \%$ & Easy \\
\hline & Suffixes & & \\
\hline 2 & ance & $2,12 \%$ & Easy \\
\hline 3 & er & $8,51 \%$ & Easy \\
\hline 4 & Ly & $8,51 \%$ & Easy \\
\hline 5 & ing & $6,38 \%$ & Easy \\
\hline 6 & ly & $19,14 \%$ & Easy \\
\hline 7 & ly & $10,63 \%$ & Easy \\
\hline 8 & ly & $87,23 \%$ & $\begin{array}{c}\text { Difficul } \\
\mathrm{t}\end{array}$ \\
\hline 9 & ful & $17,02 \%$ & Easy \\
\hline $\begin{array}{l}\mathbf{N} \\
\mathbf{0}\end{array}$ & Suffixes & $\begin{array}{c}\text { Percentag } \\
\text { e }\end{array}$ & $\begin{array}{c}\text { Criteri } \\
\text { a }\end{array}$ \\
\hline 10 & ly & $27,65 \%$ & Easy \\
\hline 11 & ing & $8,51 \%$ & Easy \\
\hline 12 & ly & $21,27 \%$ & Easy \\
\hline 13 & ance & $40,42 \%$ & $\begin{array}{c}\text { Difficul } \\
\mathrm{t}\end{array}$ \\
\hline 14 & ing & $2,12 \%$ & Easy \\
\hline \multirow[t]{2}{*}{15} & ing & $4,25 \%$ & Easy \\
\hline & Infixes & & \\
\hline 16 & re-ly & $89,36 \%$ & $\underset{t}{\text { Difficul }}$ \\
\hline 17 & re-able & $70,21 \%$ & $\begin{array}{c}\text { Difficul } \\
t\end{array}$ \\
\hline
\end{tabular}

\begin{tabular}{|c|c|c|c|}
18 & re-ing & $61,70 \%$ & $\begin{array}{c}\text { Difficul } \\
\mathrm{t}\end{array}$ \\
\hline 19 & un-ly & $85,10 \%$ & $\begin{array}{c}\text { Difficul } \\
\mathrm{t}\end{array}$ \\
\hline 20 & un-ly & $85,10 \%$ & $\begin{array}{c}\text { Difficul } \\
\mathrm{t}\end{array}$ \\
\hline
\end{tabular}

In the first test which the title "My Son Joshua" there are 20 derivation words. After the writer calculated there are 47 students. It can be seen that it is clear the writer found errors in the first items that includes there was 1 Students who made errors in suffix ance with the percentage of $2,12 \%$. Meanwhile, there was nothing students who made errors in prefix in with the percentage of $0 \%$. Further, there were 4 students who made errors in suffix er with the percentage of $8,51 \%$. Besides, there were 4 students who made errors in suffix $l y$ with the percentage of $8,51 \%$. There were 42 students who made errors in infix re-ly with the percentage of $89,36 \%$. There were 3 students who made errors in suffix ing with the percentage of $6,38 \%$. There were 9 students who made errors in suffix ly with the percentage of $19,14 \%$. There were 33 students who made errors in infix re-able with the percentage of $70,21 \%$. There were 5 students who made errors in suffix $l y$ with the percentage of $10,63 \%$. There were 41 students who made errors in suffix ly with the percentage of $87,23 \%$. There were 29 students who made errors in infix re-ing with the percentage of $61,70 \%$. There were 8 students who made errors in suffix full with the percentage of $17,02 \%$. There were 13 students who made errors in 
suffix $l y$ with the percentage of $27,65 \%$. There were 40 students who made errors in infix un-ly with the percentage of $85,10 \%$. There were 4 students who made errors in suffix ing with the percentage of $8,51 \%$. There were 10 students who made errors in suffix $l y$ with the percentage of $21,27 \%$. There were 19 students who made errors in suffix ance with the percentage of $40,42 \%$.

There were 40 students who made errors in suffix un-ly with the percentage of $85,10 \%$. There was 1 students who made errors in suffix ing with the percentage of $2,12 \%$. There were 2 students who made errors in suffix ing with the percentage of $4,25 \%$.

So it can be concluded that there are 33 students got easy category. It get by the sample number $1,2,3,4,5$, $6,8,9,10,14,15,16,17,18,19,21$, $25,26,27,29,33,34,35,38,39,40$, $41,42,43,44,45,46,47(15,78 \%$ $40 \%$ ) and there are 14 students got difficult category. It get by the sample number $7,11,12,13,20,22,23,24$, $28,30,31,32,36,37(42,11 \%-55 \%)$.

In the first test the writer put 1 prefix, 14 suffix and 5 infix, so after analyzed it, the writer found students difficulty here. There are 42 students feel difficult to change the word become infix especially (re-ly), It caused by the students feel difficult in changing this word and much of students do not know about what is infix and how to change this one, to make students are easy in do this infix and to change the word become easy. The lecturer should teach how to change it and give come strategy in doing this one. There are 41 students feel difficult to change the word become suffix especially (ly), there are no students fouls to change the word become prefix in the first test. Because many students know about using prefix in "in" and this word most familiar in written test. Many mistake made by the students in changing this word. It caused by students seldom read and learnt about suffix. To anticipate this problem, the students should more study and exercise in their home how to change derivational word in order that they have capability in changing suffix.

So it can be concluded that to change derivational word to be infix, suffix and prefix. The students more difficult in understanding and the students more difficult in doing infix especially (re-ly, re-able, re-ing, and un-ly) and suffix especially (ly, ing, ance, er) but there are no students fouls to change prefix. This is for the first test with the title "My Son is Joshua".

For the second test the writer put 6 prefix, 11 suffix, and 3 infix, so after analyzed it, the writer found students difficulty here. There are 47 students feel difficult to change the word become infix especially (re-ment), It caused by the students feel difficult in changing this word and much of students do not know about what is infix and how to change this one, to make students are easy in do this infix and to change the word become easy. The lecturer should teach how to change it and give come strategy in doing this one. There are 38 students 
feel difficult to change the word become suffix especially (ment), there are 10 students difficult to change the word become prefix especially (in) in the second test. Many mistake made by the students in changing this word. It caused by students seldom read and learnt about suffix. To anticipate this problem, the students should more study and exercise in their home how to change derivational word in order that they have capability in changing suffix.

So it can be concluded that to change derivational word to be infix, suffix and prefix. The students more difficult in understanding and the students more difficult in doing infix especially (re-ment, re-ly), and in suffix especially (ment, ly, ity, ing, ance, ation, ness) and than in prefix especially (un, pro, in, re). This is for the first test with the title "Sources of stress".

Than the last test the writer put 8 prefix, 10 suffix, and 2 infix, so after analyzed it, the writer found students difficulty here. There are 45 students feel difficult to change the word become infix especially (an-al), It caused by the students feel difficult in changing this word and much of students do not know about what is infix and how to change this one, to make students are easy in do this infix and to change the word become easy. The lecturer should teach how to change it and give come strategy in doing this one. There are 41 students feel difficult to change the word become suffix especially (ance), there are 32 students difficult to change the word become prefix especially (in) in the third test. Many mistake made by the students in changing this word. It caused by students seldom read and learnt about suffix. To anticipate this problem, the students should more study and exercise in their home how to change derivational word in order that they have capability in changing suffix.

So it can be concluded that to change derivational word to be infix, suffix and prefix. The students more difficult in understanding and the students more difficult in doing infix especially (un-al, in-ants), and in suffix especially (ation, ly, ing, ance, ness, ful) and than in prefix especially (un, dis, per, in, re). This is for the first test with the title "Adaptations to Extreme Heat"

So the students have to be diligent do the exercise and the students should more read the book that have correlate with derivational word.

In order to make clearer about errors made by students on derivation in English affixes especially prefixes, suffixes and infix, the follow table will describe the students' classification.

Table 5.

The Percentage of Errors Made by Students on Derivation

\begin{tabular}{|c|c|c|c|}
\hline No & Category & $\begin{array}{c}\text { Number } \\
\text { of } \\
\text { Students }\end{array}$ & Percentage \\
\hline 1 & Easy & 33 & $70,21 \%$ \\
\hline
\end{tabular}




\begin{tabular}{|l|l|l|l|}
2 & Difficult & 14 & $29,78 \%$ \\
\hline Total & 47 & $100 \%$ \\
\hline
\end{tabular}

From the presentation of the data analysis above, the writer found that there were thirty three (33) students at the category "Easy" or it was just $70,21 \%$ of them could answer English derivational affixes, especially prefixes, suffixes and infix. They were the students' No. 1, 2, 3, 4, 5, 6, 8, 9, $10,14,15,16,17,18,19,21,25,26$, $27,29,33,34,35,38,39,40,41,42$, 43, 44, 45, 46, and 47. Meanwhile, There were fourteen (14) students who got the category of "Difficult", it means that $29,78 \%$ of them who had answers. They were the students' No. 7, 11, 12, 13, 20, 22, 23, 24, 28, 30, 31, 32,36 , and 37 .

Finally, in conclusion, this research was dominated by the students with difficult level of ability $(29,78 \%)$ and it was followed by the students with easy level of ability $(70,21 \%)$, from total students forty seven (47).

\section{DISCUSSION}

In the first test the writer put 1 prefix, 14 suffix and 5 infix, so after analyzed it, the writer found students difficulty here. There are 42 students feel difficult to change the word become infix especially (re-ly), It caused by the students feel difficult in changing this word and much of students do not know about what is infix and how to change this one, to make students are easy in do this infix and to change the word become easy. The lecturer should teach how to change it and give come strategy in doing this one. There are 41 students feel difficult to change the word become suffix especially (ly), there are no students fouls to change the word become prefix in the first test. Because many students know about using prefix in "in" and this word most familiar in written test. Many mistake made by the students in changing this word. It caused by students seldom read and learnt about suffix. To anticipate this problem, the students should more study and exercise in their home how to change derivational word in order that they have capability in changing suffix.

So it can be concluded that to change derivational word to be infix, suffix and prefix. The students more difficult in understanding and the students more difficult in doing infix especially (re-ly, re-able, re-ing, and un-ly) and suffix especially (ly, ing, ance, er) but there are no students fouls to change prefix. This is for the first test with the title "My Son is Joshua".

For the second test the writer put 6 prefix, 11 suffix, and 3 infix, so after analyzed it, the writer found students difficulty here. There are 47 students feel difficult to change the word become infix especially (re-ment), It caused by the students feel difficult in changing this word and much of students do not know about what is infix and how to change this one, to make students are easy in do this infix and to change the word become easy. The lecturer should teach how to 
change it and give come strategy in doing this one. There are 38 students feel difficult to change the word become suffix especially (ment), there are 10 students difficult to change the word become prefix especially (in) in the second test. Many mistake made by the students in changing this word. It caused by students seldom read and learnt about suffix. To anticipate this problem, the students should more study and exercise in their home how to change derivational word in order that they have capability in changing suffix.

So it can be concluded that to change derivational word to be infix, suffix and prefix. The students more difficult in understanding and the students more difficult in doing infix especially (re-ment, re-ly), and in suffix especially (ment, ly, ity, ing, ance, ation, ness) and than in prefix especially (un, pro, in, re). This is for the first test with the title "Sources of stress".

Than the last test the writer put 8 prefix, 10 suffix, and 2 infix, so after analyzed it, the writer found students difficulty here. There are 45 students feel difficult to change the word become infix especially (an-al), It caused by the students feel difficult in changing this word and much of students do not know about what is infix and how to change this one, to make students are easy in do this infix and to change the word become easy. The lecturer should teach how to change it and give come strategy in doing this one. There are 41 students feel difficult to change the word become suffix especially (ance), there are 32 students difficult to change the word become prefix especially (in) in the third test. Many mistake made by the students in changing this word. It caused by students seldom read and learnt about suffix. To anticipate this problem, the students should more study and exercise in their home how to change derivational word in order that they have capability in changing suffix.

So it can be concluded that to change derivational word to be infix, suffix and prefix. The students more difficult in understanding and the students more difficult in doing infix especially (un-al, in-ants), and in suffix especially (ation, ly, ing, ance, ness, ful) and than in prefix especially (un, dis, per, in, re). This is for the first test with the title "Adaptations to Extreme Heat"

So the students have to be diligent do the exercise and the students should more read the book that have correlate with derivational word.

\section{CONCLUSION}

Derivation is a process of adding affixes, such as suffix, prefix and infix to a word (David Crystal; 1999). According to Boey (1975-39) in Simarmata (2006-7) bound morpheme may be classified as affixes, which are subdivided into prefix, suffix and nfix, according to the way they are combine with the base or stem (Boey, 1975:38). Prefix occurs before base, example : (un) lucky, (pre) school, and (dis-) like. Suffix occurs after base, example : kind (-ness), angry (-ly), judge (-ment). 
Infixes occur in the middle of the base, English has no infixes.

There are two kinds of affixes, inflectional and derivational. Inflectional affixes are bound morphemes, which carry grammatical meaning, and they do not change the class of the base to which they are added, such as bag, tin, and box are noun. If we add /-s/ and /-es/ they will become bags, tins, and boxes which are still nouns. While derivational affixes are bound morphemes, which generally combined with the base to change its part of speech class (Yule, 1985).

The result of the research showed that the students mean score in answering completing paragraph especially derivation errors made by the students. From 3 sample topics paragraph that the students many errors made by the students in changing this word. And than feel difficult in changing this word and much of students do not know about derivational.

From the data above, it can be concluded, there are $89,36 \%$ students feel difficult and make error in changing the derivational error especially in infix, after that there are $87,23 \%$ students feel difficult and make error in changing the derivational error especially in suffix and there are no students make error in prefix, this conclusion for the first test.

For the second test it can be concluded, there are $100 \%$ students feel difficult and make error in changing the derivational error especially in infix, after that there are
$80,85 \%$ students feel difficult and make error in changing the derivational error especially in suffix and there are $21,27 \%$ students make error in prefix, this conclusion for the second test.

Then the last test it can be concluded, there are $95,74 \%$ students feel difficult and make error in changing the derivational error especially in infix, after that there are $87,23 \%$ students feel difficult and make error in changing the derivational error especially in suffix and there are $68,08 \%$ students make error in prefix, this conclusion for the first test.

So it can be concluded the students more difficult in changing derivational word into infix, it can be seen from the explanation above in the times test that done by the writer.

\section{REFERENCES}

Aminatuzzuhriyah. 2007. A study on the ability of the third year students of English study program of FKIP UIR in writing persuasive paragraph from advertisements of product-information format. Unpublished.

Crystal, David (1999): The Penguin Dictionary of Language. Penguin Books - England http://en.Wikipedia.org/wiki/ Derivation_(linguistics)

Connor, U. (1996) Contrastive Rhetoric: Cross-cultural Aspects of Second-Language 
Writing. Cambridge: Cambridge University Press.

Corder, S.P. (1981) Error Analysis and Interlanguage. Oxford: Oxford University Press.

Ellis, R. (1995) Understanding Second Language Acquisition. (10th ed.) Oxford: Oxford University Press.

Halliday, M.A.K. \& Hasan, R. (1976) Cohension in English. London: Longman.

Hornby, As 1989. Guide to Pattern and Usage in English. Great Britain: Oxford University Press.

James, C. (1998) Errors in Language Learning and Use. London: Longman.

Jurafsky, Daniel and H. Martin James, 2000, Speech and Language Processing, Prentice- Hall, inc, 63-64. includes bibliographical references and index

Kamil Wisniewski

July06th,2007/http://www.tlumaczeni aangielski.info/linguistics/wor d-formation.htm

Langacker, R.W. 1973. Language and Its Structure: Some Fundamental Linguistics Concepts. New York. Harcourt Brace Jovanovich Inc.

Lengo, Nsakala. 1995. What is an Error? Forum (online), Vol.33. No.3, (http//exchanges.states.gov/fo rum/).

Liu, M. \& Braine, G. (2005) Cohesive Features in Argumentative Writing Produced by Chinese Undergraduates. System, 33: 623-636.

L.T.Covell: 1861: A digest of English grammar: synthectical and analytical-halaman 18

Merriam. 2009. http://www.merriamwebster.com/dictionary/writin g

Nida, E.A. 1949. Morphology: The Descriptive Analysis of words. Ann Arbor. The University of Michigan Press.

Norrish, J. (1983) Language Learners and Their Errors. London: Macmillan Press.

Raimes,A. 1983. Technique In Teaching Writing. Oxford University Perss.

Richards, Jack C. 1974. Error Analysis. London : Longman.

Seno, H.Putra. 2006. Morphosyntax of Talang Mamak Dialect. Pekanbaru: Unri Press.

Seno, H.Putra. 2008. Al-qur'an: Linguistics and Culture Involve in Science and Technology. Orasi Ilmiah Guru Besar. Pekanbaru.

Voss, Ralph F and Michael L. Keene. The Heath Guide to Collage Writing. 1992.D.C. Heath and Company. 